\title{
Patient-Reported Outcomes of Chemotherapy Involving Non-Small Cell Lung Cancer: Evaluation by Questionnaires of Quality of Life Regarding Anti-Aging and Anti-Cancer Drugs
}

\author{
Takanori Ayabe', Masaki Tomita1, Takashi Asada1, Kazuyo Tsuchiya1, Manabu Nemoto², \\ Kunihide Nakamura ${ }^{3}$ \\ ${ }^{1}$ Division of Thoracic and Breast Surgery, Department of Surgery, Miyazaki, Japan \\ ${ }^{2}$ Department of Surgery, Junwakai Memorial Hospital, Miyazaki, Japan \\ ${ }^{3}$ Division of Cardiovascular Surgery, Department of Surgery, Faculty of Medicine, University of Miyazaki, Miyazaki, Japan \\ Email: tayabe@med.miyazaki-u.ac.jp
}

How to cite this paper: Ayabe, T., Tomita, M., Asada, T., Tsuchiya, K., Nemoto, M. and Nakamura, K. (2017) Patient-Reported Outcomes of Chemotherapy Involving NonSmall Cell Lung Cancer: Evaluation by Questionnaires of Quality of Life Regarding Anti-Aging and Anti-Cancer Drugs. $A d$ vances in Lung Cancer, 6, 13-35.

https://doi.org/10.4236/alc.2017.62002

Received: March 20, 2017

Accepted: June 19, 2017

Published: June 22, 2017

Copyright $\odot 2017$ by authors and Scientific Research Publishing Inc. This work is licensed under the Creative Commons Attribution International License (CC BY 4.0).

http://creativecommons.org/licenses/by/4.0/

\begin{abstract}
Background: Patient-reported outcomes (PROs) of quality of life (QOL) during chemotherapy involving lung cancer are very important for the medical staffs. Patients' satisfaction and healthy changes were evaluated by the patient-self assessment. Materials and Methods: From July 2007 to April 2008, a total of 19 patients received chemotherapy. The QOL data were collected by using the QOL questionnaire for cancer patients treated with anticancer drugs (QOL-ACD) and the anti-aging QOL assessment (AA-QOL). The AA-QOL contained 51 items: 30 of physical and 21 of mental symptoms of the elderly and the aging population. The patients replied to the questions at two different times, i.e., at pre-chemotherapy (baseline) and at post-chemotherapy (2 weeks after the chemotherapy). Results: Regarding the hematological toxicities, for the grade $3 / 4$ toxicities, there were 12 neutropenia $(12 / 19,63.2 \%)$ and 3 thrombocytopenia $(3 / 19,15.8 \%)$. For the grade 3 febrile neutropenia, there were 5 cases $(5 / 19,26.3 \%)$. Regarding the non-hematological toxicities, there was no grade 3 and grade 4 toxicities. Based on the outcomes of the QOL$\mathrm{ACD}$, the three items ("physical condition", "social attitude", and "overall QOL") at post-chemotherapy became significantly worse compared to the baseline. Regarding the outcomes of the AA-QOL, 4 items of physical symptoms ("thirst", "anorexia", "early satiety", and "diarrhea") became significantly worse compared to the baseline. Regarding the mental symptoms, 2 items ("nothing to look forward in life" and "a sense of uselessness") became significantly worse compared to the baseline. Conclusion: Regarding the PROs of the QOL during the chemotherapy term, both the physical and mental symp-
\end{abstract}


toms had become worse. To clarify the changes in the QOL during chemotherapy is very important for multidisciplinary teamwork, which should play the role of providing the appropriate cares and treatment as patientsupport.

\section{Keywords}

Patient-Reported Outcome, Chemotherapy, Quality of Life, Non-Small Cell Lung Cancer

\section{Introduction}

Lung cancer is one of the most common malignancies and remains the leading cause of cancer-related deaths in Europe and the USA [1] [2], and also in Japan [3]. The impact of chemotherapy on the survival and quality of life (QOL) on advanced non-small cell lung cancer (NSCLC) has long been the subject of debate and led to the publication of five meta-analyses of randomized trials between 1993 and 1999 testing the addition of only chemotherapy as the best supportive care [4] [5] [6] [7]. These meta-analyses concluded that chemo- therapy, mainly cisplatin-based regimens, had a modest beneficial impact on survival, with a $10 \%$ improvement in the 1-year survival and an estimated gain in the median survival of 1.5 months [6].

Although platinum-based doublets involving newer agents, such as docetaxel, paclitaxel, gemcitabine, vinorelbine, and irinotecan, are the standard first-line chemotherapy for most patients with advanced NSCLC [8] [9], the use of these regimens in elderly patients remains a topic of debate [10]. The main reasons given for withholding standard platinum-based doublet regimens from elderly patients are the age-related impairment of organ functions, presence of potentially complicating comorbid conditions, and a lower ability to tolerate the potential toxicity of the combination chemotherapy than younger patients.

More recent randomized trials of adjuvant cisplatin-based chemotherapy have shown only a marginally better compliance despite considerable improvements in the supportive care medications available over the past decade. North American [11], Japanese [12], and European [13] [14] [15] intergroup trials reported that only $58 \%-69 \%$ of patients received all of the planned cycles of chemotherapy.

The World Health Organization defined the QOL as "individual" perceptions of their position in life in the context of their culture and value systems in which they live and in relation to their goal, expectation, standards and concerns" [16]. The impact of disease and treatment-related symptoms on the health-related quality of life (HR-QOL) was assessed using the self-administered European Organization for Research and Treatment of Cancer Quality of Life Questionnaire Core 30 (EORTC QLQ-C30) questionnaire (QLQ-C30) version 3.0 and the associated EORTC Quality of Life Lung Cancer-Specific Module (EORTC QLQ- 
LC13) [17] [18]. The QOL in patients with NSCLC receiving chemotherapy was mainly studied using the EORTC QLQ questionnaire [19]-[24].

However, regarding the HR-QOL in the chemotherapy of lung cancer, it is important to assess the clinical outcome based on the patient's aspect. There are very few studies about the QOL, especially about patient-reported outcomes (PROs). It is also difficult for doctors and nurses to evaluate the patients' QOL as comprehensive and objective indicators. PROs include areas of the HR-QOL, but also broader concepts such as patient satisfaction with care and treatment.

We previously reported the PRO of the surgery of lung cancer by an evaluation based on the questionnaires of the anti-aging quality of life (AA-QOL) and EORTC-C30 QLQ [25]. In case of the surgical modality, the healthy changes represented that the physical symptoms became worse compared to the mental symptoms. The PRO for surgery is very important for multidisciplinary teamwork, which should play a role in providing the appropriate care and treatments and useful information for a preoperative patient's decision making of receiving surgical treatment.

The aim of the present study is to clarify the patient's satisfaction and healthy changes of the patients receiving chemotherapy for lung cancer, which is an evaluation to be performed by the patient's self-assessment. We did not use the famous and the most world-widely-used EORTC QLQ questionnaire survey in this study. However, we used two patient-reported questionnaire surveys of the QOL; one is the QOL questionnaire for cancer patients treated with anticancer drugs (QOL-ACD), which consists of four domains (functional, physical, mental, and psychosocial), and a global face scale developed as a generic questionnaire for Japanese cancer patients undergoing chemotherapy [26]. The other is the anti-aging QOL assessment (AA-QOL), which is specific for 30 physical and 21 mental symptoms for the Japanese elderly population [27].

\section{Materials and Methods}

\subsection{Patients}

This study was approved by the University of Miyazaki Hospital Clinical Research Ethics Board. The procedures used in this study were in accordance with the Helsinki Declaration. From July 2007 to April 2008, a total of 19 patients, who received neoadjuvant therapy, adjuvant therapy, and intensive chemotherapy for recurring cases of the CBDCA-GEM or CBDCA-PTX or CDDP + DOC doublet combinations and DOC monotherapy. The characteristics of the 19 patients entered in this study are summarized in Table 1 . The TNM classification is based on the Union for International Cancer Control (UICC) [28]. The histological analysis of the tumor was based on the World Health Organization classification for cell types [29]. Patients with histologically documented NSCLC and pathologically staged were eligible to receive induction chemotherapy, adjuvant chemotherapy after complete resection of the primary tumor and mediastinal lymph nodes in our department. The patient selection was at the discretion of the attending physicians. All patients provided informed consent before the 
treatment.

\subsection{Each Patient Had to Meet the Following Eligibility Criteria}

Pathological stage diagnosed with IB to IV, Eastern Cooperative Oncology Group Performance Status of 0,1 or 2, adequate bone marrow function (total leukocyte count $\geq 4.0 \times 10^{9} / \mathrm{L}$, hemoglobin concentration $\geq 10.0 \mathrm{~g} / \mathrm{dl}$, platelet count $\geq 100 \times 10^{9} / \mathrm{L}$ ), adequate liver and renal function (serum transaminase $\leq 2$ times normal value; serum creatinine $\leq 1.5$ times normal value), partial pressure of arterial oxygen $\left(\mathrm{paO}_{2}\right) \geq 60$ torr, past history of severe allergic reaction to drugs, interstitial pneumonia identified by computed-tomography of chest, cirrhosis, or other serious complications, such as uncontrolled angina pectoris, myocardial infarction within 3 months, heart failure, uncontrolled diabetes mellitus or hypertension, and uncontrolled massive pleural effusion or ascites, no postoperative complications, able to undergo first course treatment in an inpatient setting within 4 to 8 weeks after surgery, and written informed consent.

Table 1. Patient characteristics $(n=19)$.

\begin{tabular}{|c|c|c|}
\hline Gender & Male/Female & $13 / 6$ \\
\hline \multirow[t]{2}{*}{ Age (year) } & Mean \pm SD & $66.2 \pm 10.1$ \\
\hline & Range & $44-86$ \\
\hline ECOG-PS & $0 / 1$ & $19 / 0$ \\
\hline Surgery & Lobectomy & 19 \\
\hline \multirow[t]{2}{*}{ Histology } & Adenocarcinoma & 17 \\
\hline & Squamous cell carcinoma & 2 \\
\hline \multirow[t]{4}{*}{ Pathological stage } & IIA & 2 \\
\hline & IIIA & 9 \\
\hline & IIIB & 3 \\
\hline & IV & 5 \\
\hline \multirow[t]{3}{*}{ Chemotherapy } & Neoadjuvant therapy & 3 \\
\hline & Adjuvant therapy & 11 \\
\hline & $\begin{array}{l}\text { Intensive chemotherapy for } \\
\text { recurrence }\end{array}$ & 5 \\
\hline \multirow[t]{4}{*}{ Regimen } & GEM + CBDCA & 13 \\
\hline & $\mathrm{PTX}+\mathrm{CBDCA}$ & 3 \\
\hline & $\mathrm{DOC}+\mathrm{CDDP}$ & 2 \\
\hline & DOC & 1 \\
\hline Planned cycles & $2 / 3 / 4$ cycles & $8 / 3 / 8$ \\
\hline Received cycles & $2 / 3 / 4$ cycles & $8 / 3 / 8$ \\
\hline \multirow[t]{2}{*}{ Compliance } & Dose reduction & $5 / 19(26.3 \%)$ \\
\hline & Delayed & $1 / 19(5.3 \%)$ \\
\hline \multirow[t]{2}{*}{ Response evaluation } & Partial response & $3(37.5 \%, 3 / 8)$ \\
\hline & Stable disease & $5(62.5 \%, 5 / 8)$ \\
\hline Toxicities & $\geq$ Grade $3 / 4$ & $14 / 19(73.7 \%)$ \\
\hline
\end{tabular}

ECOG-PS: Eastern Cooperative Oncology Group Performance Status, GEM: Gemcitabine, CBDCA: Carboplatin, PTX: Paclitaxel, CDDP: Cisplatin, DOC: Docetaxel. 


\subsection{Treatment Schedule}

All patients received one protocol from the prepared four treatment regimens by the attending doctors' direction and/or patients' favorable selection depending on the regimen's toxicities. The body surface area was calculated using the $\mathrm{Du}$ Bois equation. The carboplatin dosage calculation was based on the glome- rular filtration rate according to the Calvert formula [30], and evaluated by the Cockcroft-Gault equation [31]. The administration of the carboplatin dosage was adjusted prior to each cycle through redetermination of the glomerular filtration rate.

\subsubsection{Gemcitabine plus Carboplatin Regimen}

Gemcitabine (Gemzarø, Eli Lilly Japan K.K., Kobe, Japan) was administered at a dose of $1000 \mathrm{mg} / \mathrm{m}^{2}$ on days 1 and 8, and carboplatin (Paraplatin ${ }^{\oplus}$, Bristol-Myers K.K., Tokyo, Japan) with the target dose of area under the curve (AUC) of 4 on day 8 every 28 days. Premedication was intravenously performed by drip infusion of $100 \mathrm{ml}$ of isotonic sodium chloride solution containing $8 \mathrm{mg}$ of dexamethasone sodium phosphate and $3 \mathrm{mg}$ of granisetron hydrochloride. On days 1 and 8 , the intravenous (i.v.) administration of $1000 \mathrm{mg} / \mathrm{m}^{2}$ gemcitabine mixed in $100 \mathrm{ml}$ of isotonic sodium chloride solution was performed by drip infusion for 30 minutes. On day 8, carboplatin with the calculated dose of the AUC mixed in $250 \mathrm{ml}$ of a $5 \%$ glucose solution was administered for 1 hour, following the drip infusion of gemcitabine.

\subsubsection{Paclitaxel plus Carboplatin Regimen}

Paclitaxel (Paclitaxel', Bristol-Myers K.K., Tokyo, Japan) was administered at a dose of $70 \mathrm{mg} / \mathrm{m}^{2}$ on days 1,8 and 15 , and carboplatin (Paraplatin ${ }^{\oplus}$, BristolMyers K.K., Tokyo, Japan) with the target dose of AUC of 5 on day 1 every 28 days. As a premedication, $50 \mathrm{mg}$ of diphenhydramine hydrochloride was intravenously infused. The drip infusion of $50 \mathrm{ml}$ of an isotonic sodium chloride solution containing $8 \mathrm{mg}$ of dexamethasone sodium phosphate, $50 \mathrm{mg}$ of ranitidine hydrochloride and $10 \mathrm{mg}$ of azasetron hydrochloride was performed. After the administration of seventy $\mathrm{mg} / \mathrm{m}^{2}$ of paclitaxel in $250 \mathrm{ml}$ of a $5 \%$ glucose solution for over 1 hour, carboplatin with the calculated dose of the AUC mixed in $250 \mathrm{ml}$ of a 5\% glucose solution was intravenously infused for 1 hour.

\subsubsection{Docetaxel plus Cisplatin Regimen}

Docetaxel (Taxotere ${ }^{\oplus}$, Sanofi K.K., Tokyo, Japan) was administered at a dose of $60 \mathrm{mg} / \mathrm{m}^{2}$ on day 1 , and cisplatin (Platosin ${ }^{\oplus}$, Phizer Japan, Inc., Tokyo, Japan) on day 1 every 28 days. The drip infusion of $100 \mathrm{ml}$ of an isotonic sodium chloride solution containing $8 \mathrm{mg}$ of dexamethasone sodium phosphate and $3 \mathrm{mg}$ of granisetron hydrochloride was performed. After the administration of $60 \mathrm{mg} / \mathrm{m}^{2}$ of docetaxel in $250 \mathrm{ml}$ of a $5 \%$ glucose solution for over 1 hour, $80 \mathrm{mg} / \mathrm{m}^{2}$ of cisplatin in $500 \mathrm{ml}$ of an isotonic sodium chloride solution was intravenously infused for 2 hours. As hydration, drip infusions of $500 \mathrm{ml}$ of an isotonic sodium chloride solution for over 2 hours, $500 \mathrm{ml}$ of a $5 \%$ glucose solution for over 2 hours, 
and $500 \mathrm{ml}$ of a maintenance solution with electrolyte for over 2 hours were performed. The drip infusion of $300 \mathrm{ml}$ of a $20 \%$ of D-mannitol for over 1 hour was performed. A $20 \mathrm{mg}$ amount of furosemide was intravenously injected.

\subsubsection{Docetaxel Regimen}

Docetaxel (Taxotere ${ }^{\oplus}$, Sanofi K.K., Tokyo, Japan) was administered at a dose of $60 \mathrm{mg} / \mathrm{m}^{2}$ on day 1 every 21 days. The drip infusion of $100 \mathrm{ml}$ of an isotonic sodium chloride solution containing $8 \mathrm{mg}$ of dexamethasone sodium phosphate and $3 \mathrm{mg}$ of granisetron hydrochloride was performed. The drip infusion of 250 $\mathrm{ml}$ of an isotonic sodium chloride solution containing $60 \mathrm{mg} / \mathrm{m}^{2}$ of docetaxel (Taxotere ${ }^{\oplus}$, Sanofi K.K., Tokyo, Japan) for over 1 hour was performed.

\subsubsection{The Exclusion Criteria}

The exclusion criteria included serious infection, fever $\left(\geq 38^{\circ} \mathrm{C}\right)$, impairments of an organ function (bone marrow, central nervous and cardiovascular system, liver, kidneys, interstitial pneumonia, and disseminated intravascular coagulation), patient's refusal and attending doctor's decision.

\subsection{Toxicity}

Prior to receiving the chemotherapy, all patients provided a complete medical history and underwent a physical examination. Patients were monitored weekly throughout the treatment by physical examination, recording of toxic effects, complete blood cell counts, and blood chemistry. These patients were examined for their background characteristics, adverse events, treatment compliance and relapse-free survival. Adverse events (AE) were evaluated for 4 weeks after the completion of the chemotherapy according to the Common Terminology Criteria for Adverse Events Version. 3.0 (CTCAE v3.0). The CTCAE v3.0 displays Grades 1 through 5 with unique clinical descriptions of severity for each adverse event based on this general guideline: Grade 1, mild AE; Grade 2, moderate AE; Grade 3, severe AE; Grade 4, life-threatening or disabling AE; grade 5, Death related to AE. Grade 3/4 thrombocytopenia (grade 3, <50.0 - 25.0 × 10 $/ 1$; grade 4, $<25.0 \times 10^{9} / 1$ ) and grade $1 / 2$ alopecia (grade 1 , thinning or patchy; grade 2 , complete) were defined.

\subsection{The Patient-Centered Outcomes of Quality of Life}

The QOL data were collected using questionnaires from the QOL questionnaire for cancer patients treated with anticancer drugs (QOL-ACD) and the Anti-aging Quality-of-Life Assessment (AA-QOL). The questionnaires of the QOLACD and the AA-QOL were used to obtain the patient-centered QOL during the chemotherapy treatment period. The patients replied to the questionnaires at different times. i.e., before and after chemotherapy, which was at the pre-chemotherapy (baseline) and at the post-chemotherapy (2 weeks after the chemotherapy). The obtained data of these scores at the pre-chemotherapy and the post-chemotherapy times were averaged and compared between the two groups, of which the changes were represented as the second evaluation of the QOL. 


\subsubsection{The Quality of Life Questionnaire for Cancer Patients Treated with Anticancer Drugs (QOL-ACD)}

The QOL questionnaire for cancer patients treated with anticancer drugs (QOL-ACD), which consists of four domains (functional, physical, mental, and psychosocial) and a global face scale, was developed as a generic questionnaire for Japanese cancer patients undergoing chemotherapy [26]. Matsumoto T. et al. [32] examined the validity and reliability of this questionnaire of Japanese patients with advanced NSCLC who participated in two randomized phase III trials. The results confirmed the high reliability of the questionnaire. The results of a factor analysis provided strong support for the domain structure used in the questionnaire. Each of the four domains had a moderate to strong association with important clinical variables, such as performance status or weight loss, and a correlation analysis showed that the face scale provided an appropriate measure of the global QOL. The QOL-ACD is potentially useful for clinical research regarding Japanese patients with advanced NSCLC.

\subsubsection{Anti-Aging Quality of Life Assessment (AA-QOL)}

Observation of improvement in the QOL was used by a common interview sheet. At the baseline and after surgery, any improvement in the QOL, i.e., "physical symptoms" and "mental symptoms" as subjective symptoms, were evaluated using a five-point scale (1-point: absolutely none; 2-point: almost not; 3point: mild, 4-point: moderate; 5-point:severe) using the Anti-aging QOL Common Questionnaire (AA-QOL) [27].

The symptomatic evaluated items are 30 physical symptoms and 21 mental ones. The physical symptoms are listed as "tired eyes", "blurry eyes", "eye pain", "stiff shoulders", "muscular pain/stiffness", "palpitations”, “dyspnea”, "tendency to gain weight", "weight loss; thin", "lethargy", "no feeling of good health", "thirst", "skin problems", "anorexia", "early satiety", "epigastralgia", "liable to catch colds", "coughing and sputum", "diarrhea', "constipation”, "headaches”, “dizziness", "tinnitus", "lumbago", “arthralgia”, “edematous”, “easily breaking into a sweat", "frequent urination", "hot flash", and "cold skin". Mental symptoms are listed as "irritability", "easily angered", "loss of motivation", "no feeling of happiness", "nothing to look forward in life", "daily life is not enjoyable", "loss of confidence", "reluctance to talk with others", "depressed", "a sense of uselessness", "shallow sleep", "difficulty falling asleep", "pessimism", "lapse of memory", "inability of concentrate", "inability to solve problems", "inability to readily make judgements", "inability to sleep because of worries", "a sense of tension", "feeling of anxiety for no special reason", and "a vague feeling of fear". The physical symptoms and mental symptoms were evaluated using a five-point scale (1 through 5).

To perform the second evaluation of the QOL scores using the five-point scale, we evaluated the transition of the QOL scores regarding each symptom before and after chemotherapy. We determined a significant change in the second evaluation of the QOL score, when the values changed more than $10 \%$ from the baseline score. We allocated the changed rates of each symptom before 
and after chemotherapy, i.e., as three types, that is improved (“ $\uparrow$ "; increased more than $10 \%$ ), unchanged (" $\rightarrow$ "; changed within $\pm 10 \%$ ), and worse (“ $\downarrow$ "; decreased less than $-10 \%)$.

\subsection{Statistical Analysis}

A statistical analysis of the results was performed using the paired t-test. A value of $\mathrm{p}<0.05$ was considered to indicate a statistically significant change. A statistical analysis of the results was performed using the paired t-test for comparison of the values between the level at the baseline and that after 8 weeks of administration in each group.

\section{Results}

\subsection{Patient Characteristics}

A total of 19 patients (13 males and 6 females) received chemotherapy in our department as summarized in Table 1 . The majority of patients were males $(13 / 19,68.4 \%)$ with a median age of $66.2 \pm 10.1$ years (range $44-86)$. The ECOG performance status was 0 in the 19 patients $(19 / 19,100 \%)$. A lobectomy was performed in the 19 patients $(19 / 19,100 \%)$. Tumor histology included 17 patients with adenocarcinoma (89.5\%), and 2 patients with squamous cell carcinoma (10.5\%). There were 2 patients with stage IIA (10.5\%), 9 patients with stage IIIA (47.4\%), 3 patients with stage IIIB (15.8\%), and 5 patients with stage IV (26.3\%). The GEM + CBDCA regimen was performed for 13 patients (13/19, 68.4\%), PTX + CBDCA was for 3 patients $(3 / 19,15.8 \%)$, DOC + CDDP for 2 patients $(2 / 19,10.5 \%)$, and DOC monotherapy for 1 patient $(1 / 19,5.3 \%)$. The toxicities of more than grade 3 and/or grade 4 were observed in 14 patients (14/19, $73.7 \%)$.

\subsection{Treatment Background}

A total of 57 chemotherapy cycles of the planned $2(n=8), 3(n=3)$, and 4 cycles $(\mathrm{n}=8)$ were administered as listed in Table 1 . Regarding the compliance, all patients $(100 \%, 19 / 19)$ received the scheduled cycles. Five patients $(26.3 \%$, $5 / 19)$ received a dose reduction in the next course. One patient $(5.3,1 / 19 \%)$ delayed the course.

\subsection{Treatment Response}

Regarding the final effect of treatment, that is neo adjuvant therapy $(\mathrm{n}=3)$ and intensive chemotherapy for recurring cases $(n=5)$, there were 3 partial responses for an overall response rate of $37.5 \%(3 / 8)$ as listed in Table 1 . In addition, 5 patients $(62.5 \%, 5 / 8)$ had stable diseases.

\subsection{Toxicity}

Table 2 shows the hematological toxicities. For the grade 4 toxicities, there were 7 neutropenia $(7 / 19,36.8 \%)$ and 3 thorambocytopenia $(3 / 19,15.8 \%)$. For the 
grade $3 / 4$ toxicities, there were 12 neutropenia $(12 / 19,63.2 \%)$ and 9 thorambocytopenia $(9 / 19,47.4 \%)$. For the grade 3 febrile neutropenia, there were 5 cases $(5 / 19,26.3 \%)$.

Table 3 shows the non-hematological toxicities. There were no grade 3 and grade 4 toxicities. For the grade 2 toxicities, there were 2 anorexia (2/19, 10.5\%), 2 fatigue $(2 / 19,10.5 \%), 5$ alopecia $(5 / 19,26.3 \%), 1$ fever $(1 / 19,5.3 \%)$, and 1 other (healing) $(1 / 19,5.3 \%)$.

\subsection{Patient-Centered Outcomes of Quality of Life}

\subsubsection{Patient-Reported Outcomes of QOL-ACD}

Table 4 shows the assessment results of the factors of "daily-life activities", "physical condition", "psychology condition", "social attitude", "face scale", and “overall QOL”. The four items (“daily-life activities”, "physical condition", "face scale", and "overall QOL") at post-chemotherapy significantly resulted in a worse QOL compared to the values at pre-chemotherapy (the baseline). The scale of "daily-life activities" significantly decreased, which changed from 25.3 \pm 5.1 at the baseline to $20.7 \pm 6.8$ at post-chemotherapy $(p=0.013)$. The scale of

Table 2. Outcomes for hematological toxicities.

\begin{tabular}{ccccccc}
\hline Toxicity & Grade 1 & Grade 2 & Grade 3 & Grade 4 & Grade 3/4 (\%) \\
\hline Leukopenia & 8 & 5 & 0 & 0 & 0 & $(63.2)$ \\
Neutropenia & 3 & 3 & 5 & 7 & 12 & 0 \\
Anemia & 3 & 4 & 0 & 0 & 9 & $(47.4)$ \\
Thrombocytopenia & 0 & 3 & 6 & 3 & 5 & $(26.3)$ \\
Febrile neutropenia & 0 & 0 & 5 & 0 & \\
\hline
\end{tabular}

Table 3. Outcomes for non-hematological toxicities.

\begin{tabular}{ccccc}
\hline Toxicity & Grade 1 & Grade 2 & Grade 3 & Grade 4 \\
\hline Nausea & 16 & 0 & 0 & 0 \\
Vomiting & 1 & 0 & 0 & 0 \\
Anorexia & 13 & 2 & 0 & 0 \\
Fatigue & 13 & 2 & 0 & 0 \\
Diarrhea & 2 & 0 & 0 & 0 \\
Constipation & 2 & 0 & 0 & 0 \\
ALT/AST & 0 & 0 & 0 & 0 \\
Creatinine & 0 & 0 & 0 & 0 \\
Neuropathy & 0 & 0 & 0 & 0 \\
Pain, joint & 1 & 0 & 0 & 0 \\
Pain, muscle & 1 & 0 & 0 & 0 \\
Skin rash & 1 & 0 & 0 & 0 \\
Alopecia & 1 & 5 & 0 & 0 \\
Infection & 0 & 0 & 0 & 0 \\
Fever & 5 & 1 & 0 & 0 \\
Others (hearing) & 0 & 0 & 0 & 0 \\
\hline
\end{tabular}


Table 4. Outcomes for QOL-ACD.

\begin{tabular}{ccccc}
\hline \multirow{2}{*}{ Scale } & & Pre-chemotherapy & Post-chemotherapy & \\
\cline { 3 - 4 } & Items $^{*}$ & (Scores at baseline) & (Scores at 2 weeks) & \\
\hline Daily-life activities & $1-6$ & $25.3 \pm 5.1$ & $20.7 \pm 6.8$ & 0.013 \\
Physical condition & $7-11$ & $21.5 \pm 3.2$ & $16.4 \pm 4.5$ & $<0.001$ \\
Psychological condition & $12-16$ & $18.6 \pm 4.1$ & $16.8 \pm 4.3$ & 0.091 \\
Social attitude & $17-21$ & $13.9 \pm 3.8$ & $13.2 \pm 5.0$ & 0.306 \\
Face scale & 22 & $3.8 \pm 0.9$ & $2.9 \pm 0.9$ & 0.003 \\
Overall QOL & & $83.1 \pm 12.1$ & $69.9 \pm 17.2$ & 0.005 \\
\hline
\end{tabular}

*Numbers correspond to item numbers on the 22-item questionnaire (QOL-ACD).

"physical condition" significantly decreased, which changed from $21.5 \pm 3.2$ at the baseline to $16.4 \pm 4.5$ at post-chemotherapy ( $<0.001)$. The scale of "face scale" significantly became worse, which changed from $3.8 \pm 0.9$ at the baseline to $2.9 \pm 0.9$ at post-chemotherapy $(\mathrm{p}=0.003)$. The scale of "overall QOL" significantly showed a worse change, which changed from $83.1 \pm 12.1$ at the baseline to $69.9 \pm 17.2$ at post-chemotherapy $(\mathrm{p}=0.005)$. For the other scales of "psychology condition" and "social attitude", the values at post-chemotherapy appeared to undergo a similar change compared to the values at the baseline, however, there were no significant changes.

\subsubsection{Patient-Reported Outcomes of AA-QOL}

Table 5 shows the values of 30 items of the physical symptoms. Seven symptom items ("lethargy", "thirst", "anorexia", "early satiety", "liable to catch colds", "diarrhea", and "constipation") became significantly worse compared to those at pre-chemotherapy.

The symptom of "lethargy" changed from $2.2 \pm 1.1$ at pre-chemotherapy (at the baseline) to $3.2 \pm 1.2$ at post-chemotherapy $(\mathrm{p}=0.004)$ (an increase of 1.5fold magnitude). The symptom of "thirst" changed from $1.7 \pm 0.8$ at the baseline to $2.5 \pm 1.2$ at post-chemotherapy ( $\mathrm{p}=0.006$ ) (an increase of 1.5 -fold magnitude). The symptom of "anorexia" changed from $2.1 \pm 1.0$ at the baseline to 3.5 \pm 1.4 at post-chemotherapy ( $\mathrm{p}=0.001)$ (increase of 1.7 -fold magnitude). The symptom of "early satiety" changed from $1.6 \pm 0.8$ at the baseline to $2.6 \pm 1.3$ at post-chemotherapy ( $\mathrm{p}=0.001)$ (increase of 1.6 -fold magnitude). The symptom of "liable to catch colds" changed from $1.8 \pm 0.9$ at the baseline to $2.3 \pm 1.2$ at post-chemotherapy ( $\mathrm{p}=0.035)$ (increase of 1.3 -fold magnitude). The symptom of "diarrhea" changed from $1.5 \pm 0.9$ at the baseline to $2.1 \pm 1.4$ at post-chemotherapy ( $\mathrm{p}=0.049$ ) (increase of 1.4-fold magnitude). The symptom of "constipation" changed from $2.2 \pm 1.3$ at the baseline to $3.2 \pm 1.4$ at post-chemotherapy ( $\mathrm{p}$ $=0.005$ ) (increase of 1.5-fold magnitude). Regarding the second evaluation of the anti-aging QOL, 19 items were evaluated and became worse $(63.3 \%, 19 / 30)$. These symptoms become worse due to the chemotherapy, while the other 11 items were evaluated to be unchanged $(36.7 \%, 11 / 30)$. There were no symptoms that became better after the chemotherapy. 
Table 5. Outcomes for anti-aging quality of life assessment (30 items, physical symptoms).

\begin{tabular}{|c|c|c|c|c|c|}
\hline \multirow{2}{*}{$\begin{array}{c}\text { Physical symptoms (30 } \\
\text { items) }\end{array}$} & & Post-chemotherapy & \multirow{2}{*}{$\mathrm{p}$ value } & \multirow{2}{*}{$\begin{array}{c}\text { change } \\
(\%)\end{array}$} & \multirow{2}{*}{$\begin{array}{c}\text { 2nd } \\
\text { evaluation } \\
\text { of QOL }\end{array}$} \\
\hline & & (Scores at 2 weeks) & & & \\
\hline Tired eyes & $2.3 \pm 1.1$ & $2.7 \pm 1.2$ & 0.131 & 16.1 & $\uparrow$ \\
\hline Blurry eyes & $2.2 \pm 1.0$ & $2.3 \pm 1.2$ & 0.346 & 5.8 & $\rightarrow$ \\
\hline Eye pain & $1.3 \pm 0.6$ & $1.5 \pm 0.8$ & 0.145 & 16.1 & $\uparrow$ \\
\hline Stiff shoulders & $2.5 \pm 1.1$ & $2.6 \pm 1.2$ & 0.353 & 4.8 & $\rightarrow$ \\
\hline Muscular pain/stiffness & $2.0 \pm 1.1$ & $2.5 \pm 1.3$ & 0.079 & 24.5 & $\uparrow$ \\
\hline Palpitations & $1.6 \pm 0.7$ & $1.7 \pm 0.8$ & 0.353 & 5.1 & $\rightarrow$ \\
\hline Dyspnea & $1.9 \pm 1.0$ & $2.1 \pm 1.1$ & 0.247 & 11.1 & $\uparrow$ \\
\hline Tendency to gain weight & $1.7 \pm 1.0$ & $1.7 \pm 1.0$ & 0.483 & -0.7 & $\rightarrow$ \\
\hline Weight loss; thin & $2.3 \pm 1.1$ & $2.6 \pm 1.4$ & 0.163 & 15.8 & $\uparrow$ \\
\hline Lethargy & $2.2 \pm 1.1$ & $3.2 \pm 1.2$ & 0.004 & 41.4 & $\uparrow$ \\
\hline No feeling of good health & $2.5 \pm 1.1$ & $3.0 \pm 1.4$ & 0.105 & 18.0 & $\uparrow$ \\
\hline Thirst & $1.7 \pm 0.8$ & $2.5 \pm 1.2$ & 0.006 & 43.9 & $\uparrow$ \\
\hline Skin problems & $2.1 \pm 1.0$ & $2.6 \pm 1.3$ & 0.061 & 26.0 & $\uparrow$ \\
\hline Anorexia & $2.1 \pm 1.0$ & $3.5 \pm 1.4$ & 0.001 & 67.0 & $\uparrow$ \\
\hline Early satiety & $1.6 \pm 0.8$ & $2.6 \pm 1.3$ & 0.001 & 65.8 & $\uparrow$ \\
\hline Epigastralgia & $1.6 \pm 0.7$ & $2.0 \pm 1.1$ & 0.083 & 23.1 & $\uparrow$ \\
\hline Liable to catch colds & $1.8 \pm 0.9$ & $2.3 \pm 1.2$ & 0.035 & 31.0 & $\uparrow$ \\
\hline Coughing and sputum & $2.5 \pm 1.2$ & $2.7 \pm 1.0$ & 0.307 & 6.3 & $\rightarrow$ \\
\hline Diarrhea & $1.5 \pm 0.9$ & $2.1 \pm 1.4$ & 0.049 & 38.9 & $\uparrow$ \\
\hline Constipation & $2.2 \pm 1.3$ & $3.2 \pm 1.4$ & 0.005 & 48.1 & $\uparrow$ \\
\hline Headaches & $2.7 \pm 1.4$ & $2.7 \pm 1.4$ & 0.500 & 0.0 & $\rightarrow$ \\
\hline Dizziness & $2.0 \pm 1.4$ & $2.0 \pm 1.4$ & 0.500 & 0.0 & $\rightarrow$ \\
\hline Tinnitus & $1.9 \pm 0.9$ & $2.1 \pm 1.0$ & 0.188 & 13.3 & $\uparrow$ \\
\hline Lumbago & $1.7 \pm 1.0$ & $1.8 \pm 1.0$ & 0.280 & 10.0 & $\uparrow$ \\
\hline Arthralgia & $2.0 \pm 1.2$ & $2.1 \pm 1.0$ & 0.450 & 2.0 & $\rightarrow$ \\
\hline Edematous & $2.0 \pm 1.1$ & $2.6 \pm 1.3$ & 0.063 & 25.5 & $\uparrow$ \\
\hline Easily breaking into a sweat & $1.7 \pm 0.7$ & $2.1 \pm 1.3$ & 0.114 & 21.1 & $\uparrow$ \\
\hline Frequent urination & $1.5 \pm 0.7$ & $1.4 \pm 0.5$ & 0.311 & -5.7 & $\rightarrow$ \\
\hline Hot flash & $2.5 \pm 1.4$ & $2.4 \pm 1.3$ & 0.337 & -6.3 & $\rightarrow$ \\
\hline Cold skin & $1.9 \pm 0.7$ & $2.0 \pm 0.8$ & 0.283 & 7.0 & $\rightarrow$ \\
\hline
\end{tabular}

A five-point scale (1-point: absolutely none; 2-point: almost not; 3-point: mild, 4-point: moderate; 5-point: severe). Mean $\pm \mathrm{SD}$, Wilcoxo's signed rank test.

Table 6 shows the values of 21 items regarding the mental symptoms. Three symptom items ("nothing to look forward in life", "a sense of uselessness", and "shallow sleep") became significantly worse compared to those at pre-chemotherapy (at the baseline). The symptom of the "nothing to look forward in life" changed from $2.1 \pm 0.8$ at the baseline to $2.6 \pm 1.2$ at post-chemotherapy ( $\mathrm{p}=$ 
Table 6. Outcomes for anti-aging quality of life assessment (21 items, mental symptoms).

\begin{tabular}{|c|c|c|c|c|c|}
\hline \multirow{2}{*}{$\begin{array}{c}\text { Mental } \\
\text { symptoms } \\
\text { (21 items) }\end{array}$} & Pre-chemotherapy & Post-chemotherapy & \multirow{2}{*}{$\mathrm{p}$ value } & change & \multirow{2}{*}{$\begin{array}{c}\text { 2nd } \\
\text { evaluation } \\
\text { of QOL }\end{array}$} \\
\hline & (Scores at baseline) & (Scores at 2 weeks) & & $(\%)$ & \\
\hline Irritability & $1.4 \pm 0.5$ & $1.5 \pm 0.6$ & 0.299 & 6.1 & $\rightarrow$ \\
\hline Easily angered & $1.9 \pm 1.1$ & $1.8 \pm 1.2$ & 0.402 & -4.3 & $\rightarrow$ \\
\hline Loss of motivation & $2.0 \pm 0.8$ & $2.3 \pm 1.0$ & 0.193 & 11.4 & $\uparrow$ \\
\hline No feeling of happiness & $2.0 \pm 0.9$ & $2.1 \pm 0.9$ & 0.367 & 4.5 & $\rightarrow$ \\
\hline $\begin{array}{l}\text { Nothing to look } \\
\text { forward in life }\end{array}$ & $2.1 \pm 0.8$ & $2.6 \pm 1.2$ & 0.049 & 23.3 & $\uparrow$ \\
\hline Daily life is not enjoyable & $2.1 \pm 1.0$ & $2.5 \pm 1.2$ & 0.089 & 21.2 & $\uparrow$ \\
\hline Loss of confidence & $1.8 \pm 0.9$ & $2.2 \pm 1.1$ & 0.102 & 20.5 & $\uparrow$ \\
\hline $\begin{array}{c}\text { Reluctance to talk with } \\
\text { others }\end{array}$ & $2.0 \pm 1.0$ & $2.2 \pm 1.3$ & 0.218 & 13.1 & $\uparrow$ \\
\hline Depressed & $2.1 \pm 1.0$ & $2.3 \pm 1.1$ & 0.222 & 10.7 & $\uparrow$ \\
\hline A sense of uselessness & $1.9 \pm 0.9$ & $2.4 \pm 1.2$ & 0.038 & 29.9 & $\uparrow$ \\
\hline Shallow sleep & $1.8 \pm 0.7$ & $2.4 \pm 1.3$ & 0.031 & 31.9 & $\uparrow$ \\
\hline Difficulty falling asleep & $2.2 \pm 1.0$ & $2.4 \pm 1.0$ & 0.254 & 8.7 & $\rightarrow$ \\
\hline Pessimism & $2.3 \pm 1.1$ & $2.7 \pm 1.2$ & 0.101 & 18.1 & $\uparrow$ \\
\hline Lapse of memory & $2.3 \pm 1.1$ & $2.7 \pm 1.2$ & 0.097 & 19.0 & $\uparrow$ \\
\hline $\begin{array}{l}\text { Inability of } \\
\text { concentrate }\end{array}$ & $1.8 \pm 0.9$ & $2.2 \pm 1.2$ & 0.104 & 20.8 & $\uparrow$ \\
\hline Inability to solve problems & $2.4 \pm 1.2$ & $2.2 \pm 1.0$ & 0.325 & -6.0 & $\rightarrow$ \\
\hline $\begin{array}{l}\text { Inability to make } \\
\text { judgements readily }\end{array}$ & $2.1 \pm 0.9$ & $2.5 \pm 1.2$ & 0.098 & 18.7 & $\uparrow$ \\
\hline $\begin{array}{l}\text { Inability to sleep because } \\
\text { of worries }\end{array}$ & $2.1 \pm 1.1$ & $2.1 \pm 0.8$ & 0.495 & 0.2 & $\rightarrow$ \\
\hline A sense of tension & $2.0 \pm 0.9$ & $2.2 \pm 1.0$ & 0.327 & 6.4 & $\rightarrow$ \\
\hline $\begin{array}{c}\text { Feeling of anxiety for no } \\
\text { special reason }\end{array}$ & $2.3 \pm 1.1$ & $2.5 \pm 1.1$ & 0.339 & 5.8 & $\rightarrow$ \\
\hline A vague feeling of fear & $2.4 \pm 0.9$ & $2.3 \pm 1.1$ & 0.404 & -3.0 & $\rightarrow$ \\
\hline
\end{tabular}

A five-point scale (1-point: absolutely none; 2-point: almost not; 3-point: mild, 4-point: moderate; 5-point: severe), Mean $\pm \mathrm{SD}$, Wilcoxo's signed rank test.

0.049) (increase of 1.2-fold magnitude). The symptom of "a sense of uselessness" changed from $1.9 \pm 0.9$ at the baseline to $2.4 \pm 1.2$ at post-chemotherapy ( $\mathrm{p}=$ 0.038 ) (increase of 1.3-fold magnitude). The symptom of "shallow sleep" changed from $1.8 \pm 0.7$ at the baseline to $2.4 \pm 1.3$ at post-chemotherapy ( $\mathrm{p}=$ 0.031) (increase of 1.3-fold magnitude). Regarding the second evaluation of the anti-aging QOL, 12 items were evaluated that became worse $(57.1 \%, 12 / 21)$, and 9 items were evaluated to be unchanged $(42.9 \%, 9 / 21)$. There was no symptoms that became better after the chemotherapy.

\section{Discussion}

NSCLC is the leading cause of cancer mortality [3] [33] [34]. The last decade has seen significant improvement in the first- and second-line treatments of NSCLC. 
Chemotherapy prolongs survival, alleviates disease-related symptoms and can improve the QOL in the patient population compared to best supportive care [20] [21] [35] [36]. A superiority in efficacy, toxicity and QOL has been demonstrated for the new platinum-containing regimens compared to the older regimens [19] [37] [38] [40] [41] [42] [43] [44]. Non-platinum-containing regimens have also demonstrated equivalence in efficacy with differing toxicities [45] [46] [47] [48] [49]. Studies suggest that the efficacy benefits of chemotherapy are reached after 3 - 4 cycles, and further treatment beyond this may only increase the toxicity and reduce the QOL [50] [51] [52].

In contrast, adjuvant therapy for early-stage NSCLC has been the focus of many studies in the hope of reducing the relapse risk and improving survival from the $40 \%$ to $60 \%$ achieved with surgery alone [34]. Adjuvant chemotherapy for early stage NSCLC is now the standard of care, but there is little information regarding its impact on the quality of life (QOL). Bezjak A et al. [53] reported the QOL results of JBR.10, a North American, intergroup, randomized trial of adjuvant cisplatin and vinorelbine compared with observation in patients who had complete resections, stages IB to II NSCLC. The findings of this trial indicated that the negative effects of adjuvant chemotherapy on the QOL appear to be temporary, and that improvements (with a return to baseline function) are likely in most patients [53].

In 2010, the NSCLC Meta-analysis Collaborative Group [54] showed a benefit of adjuvant chemotherapy after surgery from the results that the meta-analysis of surgery plus chemotherapy versus surgery alone was based on 34 trial comparisons and 8447 patients (3323 deaths). The NSCLC Meta-analyses Collaborative Group [54] recorded a benefit of adding chemotherapy after surgery (hazard ratio [HR] $0.86,95 \% \mathrm{CI} 0.81-0.92, \mathrm{p}<0.0001$ ) with an absolute increase in survival of $4 \%(95 \%$ CI 3 - 6) at 5 years (from $60 \%$ to $64 \%$ ). There were phase III trials using four cycles of vinorelbine and cisplatin, namely the JBR.10 [55] and ANITA trials [56]. In the JBR.10 trial, 77\% of the patients required at least a one-dose reduction [55]. In the ANITA trial, the median percentage of the planned doses of vinorelbine and cisplatin were $56.3 \%$ and $76.1 \%$, respectively, because of adverse events [56]. Treatment compliance has thus to date been low in the platinum-based adjuvant chemotherapy in oversea postsurgical resection patients. In the Japanese patients, the UFT trial has only been a phase III trial to demonstrate survival benefits for patients whose NSCLCs were completely resected.

The evidence reports about the carboplatin plus gemcitabine regimen in Japan are few compared to those of carboplatin plus paclitaxel, almost all being reported from overseas [57] [58]. The gemcitabine plus carboplatin regimen was allowed to be administered in a outpatients setting due to the short drip infusion time and mild non hematological toxicities such as alopecia and gastroenterological symptoms, however, thrombocytopenia should require attention. On the other hand, carboplatin plus paclitaxel was one of the standard treatments based on significant evidence reported around the world, and was appropriate to ad- 
minister in an outpatients setting due to the mild toxicities. However, during the long-term administration, its neuropathy was frequently recognized [39]. For these reasons and the inconvenience of prolonged infusion, the weekly administration of paclitaxel was evaluated in several cancer patients, yielding a beneficial activity and reduced toxicity [59].

We previously reported the result of chemotherapy (gemcitabine plus carboplatin versus paclitaxel plus carboplatin) in elderly patients with non-small cell lung cancer [60] and that the gemcitabine plus carboplatin and paclitaxel plus carboplatin combination chemotherapies are efficacious and feasible regimens for lung cancer therapy, especially, both regimens should be considered as one of the standard therapies for elderly patients during lung cancer therapy. We also previously reported the result of adjuvant chemotherapy (gemcitabine plus carboplatin versus paclitaxel plus carboplatin), and these results demonstrated that the gemcitabine plus carboplatin and paclitaxel plus carboplatin combination chemotherapies are efficacious and feasible regimens, which should be considered as one of the standard therapies for adjuvant therapy [61].

The past decade has seen a significant interest in QOL research within oncology and palliative medicine. It is now widely accepted that some consideration of a patient's QOL must be an integral part of the optimal medical care. More recently, the term PROs or patient-reported outcome measurement (PROM) was introduced by regulatory authorities [62] as a term encompassing any measures directly obtained from the patient and including areas of HR-QOL, but also broader concepts such as patient satisfaction with care. Patient-reported HRQOL has also been found to predict the response to treatment and survival in a number of advanced solid cancers [63] [64].

The outcomes of a clinical intervention obtained by the patient, i.e., PROs, seemed to be of more importance in the future than any other outcomes like the clinical, physiological or caregiver-reported [65]. As past studies, the enhanced treatment adherence and outcomes can be obtained by paying attention to patient feedback on healthcare outcomes and patient behavior changes [65]. A PRO is any report about the status of a patient's health condition that comes directly from the patient without interpretation of the patient's response by clinicians or anyone else [65].

The outcomes are broadly classified into clinical (e.g., cure, survival), humanistic (e.g., role performance, emotional status) and economical (e.g., expenses, savings) [66]. In the clinical scenario, the outcomes can be clinician-reported (e.g., performance of the patient), caregiver-reported (e.g., functional status), physiologic (e.g., tumor size by MRI) or patient-reported (e.g., symptoms). If the patient is observed for the outcomes by clinicians, researcher or caregiver, then the outcomes become observer-reported outcomes. If the patient has revealed in the written questionnaire that he/she is experiencing morning stiffness, it is PRO, but if the clinician is asking to describe the morning stiffness, i.e., the severity and nature are considered to be observer-reported outcomes [65].

In the present study, we did not use the famous and most world-widely-used 
EORTC QLQ questionnaire survey, however, we used the two patient-reported questionnaire surveys of the QOL. One is the quality of life questionnaire for cancer patients treated with anticancer drugs (QOL-ACD), which consists of four domains (functional, physical, mental, and psychosocial) and a global face scale, which was developed as a generic questionnaire for Japanese cancer patients undergoing chemotherapy [26]. The other is the anti-aging QOL assessment (AA-QOL), which is specified for 30 physical and 21 mental symptoms for the Japanese elderly population [27].

Based on the outcomes of the QOL-ACD, the three items ("physical condition", "social attitude", and "overall QOL") at post-chemotherapy significantly showed worse results compared to the values at pre-chemotherapy (at the baseline). For the other scales of "daily-life activities", "psychology condition", and "social attitude", the values at post-chemotherapy became worse compared to the values at the baseline, however, there was no significant changes. For the outcomes of AA-QOL, 4 items of physical symptoms ("thirst", "anorexia", "early satiety", and "diarrhea") were significantly worse compared to that of baseline. For the second evaluation of AA-QOL, 19 items were observed with increased changes $(63.3 \%, 19 / 30)$, while 11 items were unchanged $(36.7 \%, 11 / 30)$. For the mental symptoms, 2 items (nothing to look forward in life and a sense of uselessness) were significantly worse compared to those at the baseline. For the second analysis of AA-QOL, 12 items were observed with increased changes $(57.1 \%, 12 / 21)$, while 9 items were unchanged $(42.9 \%, 9 / 21)$. Based on the outcomes on the symptomatic changes of the QOL after chemotherapy, both the physical and mental symptoms became worse during the chemotherapy term.

Regarding the relationship between the self-reported outcomes based on the questionnaires (QOL-ACD and AA-QOL) and clinical ones used for our four chemotherapeitc regimens, the hematological toxicities showed moderate to severe toxicities(grade $3 / 4$ toxicities were highly observed (14/1, 73.7\%). However, in contrast, the non-hematological ones mostly displayed mild toxicities (grade $1 / 2$ toxicities were highly observed). For the mild non-hematological toxicities, the adverse event could not be correctly expressed by the patient's individual sense and its degrees were a small difference in the QOL, because they were mostly ambiguous and diverse. On the other hand, the self-reported outcomes should be able to express subtle individual sense and changes in the QOL, and its physical and mental symptoms should be able to be accurately indicated as a variable of the QOL change, which information should be useful in the multidisciplinary.

Previously, we reported the PRO of the surgery of lung cancer by the evaluation based on the questionnaires of AA-QOL and EORTC-C30 QLQ [25]. Based on our results of the PRO of the surgical treatment [25], the healthy changes suggested that the physical symptoms became worse compared to the menal symptoms. However, in the present study, for the chemotherapeutic modality, the healthy changes suggested that the both physical and mental symptoms became worse. 
Based on the research of the difference between the symptoms and HR-QOL [65], although the symptoms of the patient and HR-QOL are similar, they are two different concepts. Symptom is a one-dimensional property while HR-QOL is multidimensional. Symptoms are often the main objective of treatment, mirror clinician-patient discourse and vary dynamically with time. However, for the HR-QOL, all of these items are rare. Symptoms are directly related to disease and the treatment effect, while there is an indirect relation of them with the HR-QOL. For the PRO concepts, symptoms are often considered for behavioral objective measures, but seldom for the HR-QOL. The complexity of the concepts is high for the HR-QOL, but simple in the case of symptoms.

To clarify the healthy changes of the QOL reported by a patient in chemotherapy due to lung cancers is very important for doctors and nurses, which should play a role in providing the appropriate care and treatment in order to realize a satisfaction by the patients and their support. For a patient receiving chemotherapy due to lung cancer, and for multidisciplinary teamwork, the PROs should provide very helpful information and very convenient to obtain informed consent in making a decision of receiving chemotherapy, which encourages future chemotherapeuic patients to use as a reference in considering the symptomatic and healthy changes during chemotherapeuic treatment.

\section{Conclusion}

To clarify the changes of the QOL in chemotherapy reported by a patient with lung cancers is very important for multidisciplinary teamwork, which should play a role in providing the appropriate care and treatment in order to realize a satisfactory patient-support.

\section{References}

[1] Greenlee, R.T., Hill-Harmon, M.B., Murray, T. and Thun, M. (2001) Cancer Statistics, 2001. CA: A Cancer Journal for Clinicians, 51, 15-36. https://doi.org/10.3322/canjclin.51.1.15

[2] Parkin, D.M., Pisani, P. and Ferlay, J. (1985) Estimates of the Worldwide Incidence of Eighteen Major Cancers in 1985. International Journal of Cancer, 54, 594-606. https://doi.org/10.1002/ijc.2910540413

[3] Hori, M., Matsuda, T., Shibata, A., Katanoda, K., Sobue, T., Nishimoto, H., et al. (2015) Cancer Incidence and Incidence Rates in Japan in 2009: A Study of 32 Population-Based Cancer Registries for the Monitoring of Cancer Incidence in Japan (MCIJ) Project. Japanese Journal of Clinical Oncology, 45, 884-891. https://doi.org/10.1093/jico/hyv088

[4] Grilli, R., Oxman, A.D. and Julian, J.A. (1993) Chemotherapy for Advanced NonSmall-Cell Lung Cancer: How Much Benefit Is Enough? Journal of Clinical Oncology, 11, 1866-1872. https://doi.org/10.1200/JCO.1993.11.10.1866

[5] Marino, P., Pampallona, S., Preatoni, A., Cantoni, A. and Invernizzi, F. (1994) Chemotherapy vs. Supportive Care in Advanced Non-Small-Cell Lung Cancer. Results of a Meta-Analysis of the Literature. Chest, 106, 861-865.

[6] Non-Small Cell Lung Cancer Collaborative Group (1995) Chemotherapy in NonSmall Cell Lung Cancer: A Meta-Analysis Using Updated Data on Individual Pa- 
tients from 52 Randomised Clinical Trials. BMJ, 311, 899-909. https://doi.org/10.1136/bmj.311.7010.899

[7] Souquet, P.J., Chauvin, F., Boissel, J.P., Cellerino, R., Cormier, Y., Ganz, P.A., Kaasa, S., Pater, J.L., Quoix, E., Rapp, E., et al. (1993) Polychemotherapy in Advanced Non Small Cell Lung Cancer: A Meta-Analysis. The Lancet, 342, 19-21. https://doi.org/10.1016/0140-6736(93)91882-M

[8] Schiller, J.H., Harrington, D., Belani, C.P., Langer, C., Sandler, A., Krook, J., Zhu, J. and Johnson, D.H., Eastern Cooperative Oncology Group (2002) Comparison of Four Chemotherapy Regimens for Advanced Non-Small-Cell Lung Cancer. The New England Journal of Medicine, 346, 92-98. https://doi.org/10.1056/NEJMoa011954

[9] Kubota, K., Nishiwaki, Y., Ohashi, Y., Saijo, N., Ohe, Y., Tamura, T., Negoro, S., Ariyoshi, Y., Nakagawa, K. and Fukuoka, M. (2004) The Four-Arm Cooperative Study (FACS) for Advanced Non-Small-Cell Lung Cancer (NSCLC). Proceeding of the American Society of Clinical Oncology, 22, 14S.

[10] Gridelli, C. and Shepherd, F.A. (2005) Chemotherapy for Elderly Patients with Non-Small Cell Lung Cancer: A Review of the Evidence. Chest, 128, 947-957.

[11] Keller, S.M., Adak, S., Wagner, H., Herskovic, A., Komaki, R., Brooks, B.J., Perry, M.C., Livingston, R.B. and Johnson, D.H., Eastern Cooperative Oncology Group (2000) A Randomized Trial of Postoperative Adjuvant Therapy in Patients with Completely Resected Stage II or IIIA Non-Small-Cell Lung Cancer. The New England Journal of Medicine, 343, 1217-1222. https://doi.org/10.1056/NEJM200010263431703

[12] Ichinose, Y., Tada, H., Koike, T., Nishizawa, N., Tsuchiya, R., Nagai, K., et al. (2001) A Randomized Phase III Trial of Postoperative Adjuvant Chemotherapy in Patients with Completely Resected Stage IIIA-N2 Non-Small Cell Lung Cancer: Japan Clinical Oncology Group (JCOG) 9304 Trial. Proceedings of ASCO 2001, 20, Article ID: A1241.

[13] Scagliotti, G.V., Fossati, R., Torri, V., Crinò, L., Giaccone, G., Silvano, G., Martelli, M., Clerici, M., Cognetti, F. and Tonato, M., Adjuvant Lung Project Italy/European Organisation for Research Treatment of Cancer-Lung Cancer Cooperative Group Investigators (2003) Randomized Study of Adjuvant Chemotherapy for Completely Resected Stage I, II, or IIIA Non-Small-Cell Lung Cancer. Journal of the National Cancer Institute, 95, 1453-1461. https://doi.org/10.1093/jnci/djg059

[14] Waller, D., Fairlamb, D.J., Gower, N, Milroy, R., Peake, M.D., Rudd, R.M., et al. (2003) The Big Lung Trial (BLT): Determining the Value of Cisplatin-Based Chemotherapy for All Patients with Non-Small Cell Lung Cancer (NSCLC). Preliminary Results in the Surgical Setting. Proceedings of ASCO 2003, 22, Article ID: A2543.

[15] Arriagada, R., Bergman, B., Dunant, A., Le Chevalier, T., Pignon, J.P. and Vansteenkiste, J., The International Adjuvant Lung Cancer Trial Collaborative Group (2004) Cisplatin-Based Chemotherapy in Patients with Completely Resected Non-Small-Cell Lung Cancer. The New England Journal of Medicine, 350, 351-360. https://doi.org/10.1056/NEJMoa031644

[16] (1995) The World Health Organization Quality of Life Assessment (WHOQOL): Position Paper from the World Health Organization. Social Science \& Medicine, 41, 1403-1409.

[17] Aaronson, N.K., Ahmedzai, S., Bergman, B., Bullinger, M., Cull, A., Duez, N.J., Filiberti, A., Flechtner, H., Fleishman, S.B., de Haes, J.C., et al. (1993) The European Organization for Research and Treatment of Cancer QLQ-C30: A Quality-of-Life 
Instrument for Use in International Clinical Trials in Oncology. Journal of the National Cancer Institute, 85, 365-376. https://doi.org/10.1093/jnci/85.5.365

[18] Bergman, B., Aaronson, N.K., Ahmedzai, S., Kaasa, S. and Sullivan, M. (1994) The EORTC QLQ-LC13: A Modular Supplement to the EORTC Core Quality of Life Questionnaire (QLQ-C30) for Use in Lung Cancer Clinical Trials. EORTC Study Group on Quality of Life. European Journal of Cancer, 30, 635-642.

https://doi.org/10.1016/0959-8049(94)90535-5

[19] Giaccone, G., Splinter, T.A,, Debruyne, C., Kho, G.S., Lianes, P., van Zandwijk, N., Pennucci, M.C., Scagliotti, G., van Meerbeeck, J., van Hoesel, Q., Curran, D., Sahmoud, T. and Postmus, P.E. (1998) Randomized Study of Paclitaxel-Cisplatin versus Cisplatin-Teniposide in Patients with Advanced Non-Small-Cell Lung Cancer. The European Organization for Research and Treatment of Cancer Lung Cancer Cooperative Group. Journal of Clinical Oncology, 16, 2133-2141. https://doi.org/10.1200/jco.1998.16.6.2133

[20] Helsing, M., Bergman, B., Thaning, L. and Hero, U. (1998) Quality of Life and Survival in Patients with Advanced Non-Small Cell Lung Cancer Receiving Supportive Care plus Chemotherapy with Carboplatin and Etoposide or Supportive Care Only. A Multicentre Randomised Phase III Trial. European Journal of Cancer, 34, 1036 1044. https://doi.org/10.1016/S0959-8049(97)10122-8

[21] Cullen, M.H., Billingham, L.J., Woodroffe, C.M., Chetiyawardana, A.D., Gower, N.H., Joshi, R., Ferry, D.R., Rudd, R.M., Spiro, S.G., Cook, J.E., Trask, C., Bessell, E., Connolly, C.K., Tobias, J. and Souhami, R.L. (1999) Mitomycin, Ifosfamide, and Cisplatin in Unresectable Non-Small-Cell Lung Cancer: Effects on Survival and Quality of Life. Journal of Clinical Oncology, 17, 3188-3194.

https://doi.org/10.1200/jco.1999.17.10.3188

[22] Crinò, L., Scagliotti, G.V., Ricci, S., De Marinis, F., Rinaldi, M., Gridelli, C., Ceribelli, A., Bianco, R., Marangolo, M., Di Costanzo, F., Sassi, M., Barni, S., Ravaioli, A., Adamo, V., Portalone, L., Cruciani, G., Masotti, A., Ferrara, G., Gozzelino, F. and Tonato, M. (1999) Gemcitabine and Cisplatin versus Mitomycin, Ifosfamide, and Cisplatin in Advanced Non-Small-Cell Lung Cancer: A Randomized Phase III Study of the Italian Lung Cancer Project. Journal of Clinical Oncology, 17, 3522-3530.

[23] Cardenal, F., López-Cabrerizo, M.P., Antón, A., Alberola, V., Massuti, B., Carrato, A., Barneto, I., Lomas, M., García, M., Lianes, P., Montalar, J., Vadell, C., GonzálezLarriba, J.L., Nguyen, B., Artal, A. and Rosell, R. (1999) Randomized Phase III Study of Gemcitabine-Cisplatin versus Etoposide-Cisplatin in the Treatment of Locally Advanced or Metastatic Non-Small-Cell Lung Cancer. Journal of Clinical Oncology, 17, 12-18. https://doi.org/10.1200/JCO.1999.17.1.12

[24] Roszkowski, K., Pluzanska, A., Krzakowski, M., Smith, A.P., Saigi, E., Aasebo, U., Parisi, A., Pham Tran, N., Olivares, R. and Berille, J. (2000) A Multicenter, Randomized, Phase III Study of Docetaxel plus Best Supportive Care versus Best Supportive Care in chemotherapy-Naive Patients with Metastatic or Non-Resectable Localized Non-Small Cell Lung Cancer (NSCLC). Lung Cancer, 27, 145-157. https://doi.org/10.1016/S0169-5002(00)00094-5

[25] Ayabe, T., Tomita, M., Nose, N., Asada, T. and Nakamura, K. (2017) Patient-Reported Outcomes of Surgery of Non-Small Cell Lung Cancer: Evaluation Based on the Questionnaires of Anti-Aging Quality of Life and the European Organization for the Research and Treatment of Cancer Quality of Life Questionnaire. Surgical Science, 8, 203-219. https://doi.org/10.4236/ss.2017.85024

[26] Kurihara, M., Shimizu, H., Tsuboi, K., Kobayashi, K., Murakami, M., Eguchi, K. and Shimozuma, K. (1999) Development of Quality of Life Questionnaire in Japan: Quality of Life Assessment of Cancer Patients Receiving Chemotherapy. Psycho- 
Oncology, 8, 355-363.

https://doi.org/10.1002/(SICI)1099-1611(199907/08)8:4<355::AID-PON401>3.0.CO ;2-I

[27] Yonei, Y., Iwaita, Y., Muramatsu, K. and Mizuno, Y. (2005) The Anti-Aging Secrets of Japanese Executives. Anti-Aging Medical Research, 2, 61-69.

[28] Sobin, L.H. and Fleming, I.D. (1997) TNM Classification of Malignant Tumors, Fifth Edition (1997). Cancer, 80, 1803-1804.

https://doi.org/10.1002/(SICI)1097-0142(19971101)80:9<1803::AID-CNCR16>3.0.C $\underline{0 ; 2-9}$

[29] Travis, W.D., Garg, K., Franklin, W.A., Wistuba, I.I., Sabloff, B., Noguchi, M., Kakinuma, R., Zakowski, M., Ginsberg, M., Padera, R., Jacobson, F., Johnson, B.E., Hirsch, F., Brambilla, E., Flieder, D.B., Geisinger, K.R., Thunnissen, F., Kerr, K., Yankelevitz, D., Franks, T.J., Galvin, J.R., Henderson, D.W., Nicholson, A.G., Hasleton, P.S., Roggli, V., Tsao, M.S., Cappuzzo, F. and Vazquez, M. (2006) Bronchioloalveolar Carcinoma and Lung Adenocarcinoma: The Clinical Importance and Research Relevance of the 2004 World Health Organization Pathologic Criteria. Journal of Thoracic Oncology, 1, S13-S19. https://doi.org/10.1016/S1556-0864(15)30004-6

[30] Calvert, A.H., Newell, D.R., Gumbrell, L.A., O’Reilly, S., Burnell, M., Boxall, F.E., Siddik, Z.H., Judson, I.R., Gore, M.E. and Wiltshaw, E. (1989) Carboplatin Dosage: Prospective Evaluation of a Simple Formula Based on Renal Function. Journal of Clinical Oncology, 7, 1748-1756. https://doi.org/10.1200/JCO.1989.7.11.1748

[31] Cockcroft, D.W. and Gault, M.H. (1976) Prediction of Creatinine Clearance from Serum Creatinine. Nephron, 16, 31-41. https://doi.org/10.1159/000180580

[32] Matsumoto, T., Ohashi, Y., Morita, S., Kobayashi, K., Shibuya, M., Yamaji, Y., Eguchi, K., Fukuoka, M., Nagao, K., Nishiwaki, Y. and Niitani, H. (2002) The Quality of Life Questionnaire for Cancer Patients Treated with Anticancer Drugs (QOL-ACD): Validity and Reliability in Japanese Patients with Advanced Non-Small-Cell Lung Cancer. Quality of Life Research, 11, 483-493. https://doi.org/10.1023/A:1015614505929

[33] Jemal, A., Murray, T., Ward, E., et al. (2005) Cancer Statistics, 2005. CA: A Cancer Journal for Clinicians, 55, 10-30. https://doi.org/10.3322/canjclin.55.1.10

[34] Mountain, C. (1997) Revisions in the International System for Staging Lung Cancer. Chest, 111, 1710-1717.

[35] Brown, J., Thorpe, H., Napp, V., Fairlamb, D.J., Gower, N.H., Milroy, R., Parmar, M.K., Rudd, R.M., Spiro, S.G., Stephens, R.J., Waller, D., West, P. and Peake, M.D. (2005) Assessment of Quality of Life in the Supportive Care Setting of the Big Lung Trial in Non-Small-Cell Lung Cancer. Journal of Clinical Oncology, 23, 7417-7427. https://doi.org/10.1200/jco.2005.09.158

[36] Spiro, S.G., Rudd, R.M., Souhami, R.L., Brown, J., Fairlamb, D.J., Gower, N.H., Maslove, L., Milroy, R., Napp, V., Parmar, M.K., Peake, M.D., Stephens, R.J., Thorpe, H., Waller, D.A. and West, P., Big Lung Trial Participants (2004) Chemotherapy versus Supportive Care in Advanced Non-Small Cell Lung Cancer: Improved Survival without Detriment to Quality of Life. Thorax, 59, 828-836. https://doi.org/10.1136/thx.2003.020164

[37] Bonomi, P., Kim, K., Fairclough, D., Cella, D., Kugler, J., Rowinsky, E., Jiroutek, M. and Johnson, D. (2000) Comparison of Survival and Quality of Life in Advanced Non-Small-Cell Lung Cancer Patients Treated with Two Dose Levels of Paclitaxel Combined with Cisplatin versus Etoposide with Cisplatin: Results of an Eastern Cooperative Oncology Group Trial. Journal of Clinical Oncology, 18, 623-631. 
https://doi.org/10.1200/jco.2000.18.3.623

[38] Gatzemeier, U., von Pawel, J., Gottfried, M., ten Velde, G.P., Mattson, K., de Marinis, F., Harper, P., Salvati, F., Robinet, G., Lucenti, A., Bogaerts, J. and Gallant, G. (2000) Phase III Comparative Study of High-Dose Cisplatin versus a Combination of Paclitaxel and Cisplatin in Patients with Advanced Non-Small-Cell Lung Cancer. Journal of Clinical Oncology, 18, 3390-3399. https://doi.org/10.1200/jco.2000.18.19.3390

[39] Kelly, K., Crowley, J., Bunn Jr., P.A., Presant, C.A., Grevstad, P.K., Moinpour, C.M., Ramsey, S.D., Wozniak, A.J., Weiss, G.R., Moore, D.F., Israel, V.K., Livingston, R.B. and Gandara, D.R. (2001) Randomized Phase III Trial of Paclitaxel plus Carboplatin versus Vinorelbine plus Cisplatin in the Treatment of Patients with Advanced Non-Small-Cell Lung Cancer: A Southwest Oncology Group Trial. Journal of Clinical Oncology, 19, 3210-3218. https://doi.org/10.1200/jco.2001.19.13.3210

[40] Manegold, C., Bergman, B., Chemaissani, A., Dornoff, W., Drings, P., KellokumpuLehtinen, P., Liippo, K., Mattson, K., van Pawel, J., Ricci, S., Sederholm, C., Stahel, R.A., Wagenius, G., van Walree, N. and ten Bokkel-Huinink, W. (1997) SingleAgent Gemcitabine versus Cisplatin-Etoposide: Early Results of a Randomised Phase II Study in Locally Advanced or Metastatic Non-Small-Cell Lung Cancer. Annals of Oncology, 8, 525-529. https://doi.org/10.1023/A:1008207731111

[41] Perng, R.P., Chen, Y.M., Ming-Liu, J., Tsai, C.M., Lin, W.C., Yang, K.Y. and Whang-Peng, J. (1997) Gemcitabine versus the Combination of Cisplatin and Etoposide in Patients with Inoperable Non-Small-Cell Lung Cancer in a Phase II Randomized Study. Journal of Clinical Oncology, 15, 2097-2102. https://doi.org/10.1200/JCO.1997.15.5.2097

[42] Sandler, A. and Ettinger, D.S. (1999) Gemcitabine: Single-Agent and Combination Therapy in Non-Small Cell Lung Cancer. Oncologist, 4, 241-251.

[43] Sederholm, C., Hillerdal, G., Lamberg, K., Kölbeck, K., Dufmats, M., Westberg, R. and Gawande, S.R. (2005) Phase III Trial of Gemcitabine plus Carboplatin versus Single-Agent Gemcitabine in the Treatment of Locally Advanced or Metastatic Non-Small-Cell Lung Cancer: The Swedish Lung Cancer Study Group. Journal of Clinical Oncology, 23, 8380-8388. https://doi.org/10.1200/jco.2005.01.2781

[44] Vansteenkiste, J.F., Vandebroek, J.E., Nackaerts, K.L., Weynants, P., Valcke, Y.J., Verresen, D.A., Devogelaere, R.C., Marien, S.A., Humblet, Y.P. and Dams, N.L., Leuven Lung Cancer Group. (2001) Clinical-Benefit Response in Advanced NonSmall-Cell Lung Cancer: A Multicentre Prospective Randomised Phase III Study of Single Agent Gemcitabine versus Cisplatin-Vindesine. Annals of Oncology, 12, 1221-1230. https://doi.org/10.1023/A:1012208711013

[45] Georgoulias, V., Papadakis, E., Alexopoulos, A., Tsiafaki, X., Rapti, A., Veslemes, M., Palamidas, P. and Vlachonikolis, I., Greek Oncology Cooperative Group (GOCG) for Lung Cancer (2001) Platinum-Based and Non-Platinum-Based Chemotherapy in Advanced Non-Small-Cell Lung Cancer: A Randomised Multicentre Trial. The Lancet, 357, 1478-1484. https://doi.org/10.1016/S0140-6736(00)04644-4

[46] Georgoulias, V., Ardavanis, A., Tsiafaki, X., Agelidou, A., Mixalopoulou, P., Anagnostopoulou, O., Ziotopoulos, P., Toubis, M., Syrigos, K., Samaras, N., Polyzos, A., Christou, A., Kakolyris, S., Kouroussis, C., Androulakis, N., Samonis, G. and Chatzidaki, D. (2005) Vinorelbine plus Cisplatin versus Docetaxel plus Gemcitabine in Advanced Non-Small-Cell Lung Cancer: A Phase III Randomized Trial. Journal of Clinical Oncology, 23, 2937-2945. https://doi.org/10.1200/jco.2005.04.016

[47] Gridelli, C., Gallo, C., Shepherd, F.A., Illiano, A., Piantedosi, F., Robbiati, S.F., Manzione, L., Barbera, S., Frontini, L., Veltri, E., Findlay, B., Cigolari, S., Myers, R., 
Ianniello, G.P., Gebbia, V., Gasparini, G., Fava, S., Hirsh, V., Bezjak, A., Seymour, L. and Perrone, F. (2003) Gemcitabine plus Vinorelbine Compared with Cisplatin plus Vinorelbine or Cisplatin plus Gemcitabine for Advanced Non-Small-Cell Lung Cancer: A Phase III Trial of the Italian GEMVIN Investigators and the National Cancer Institute of Canada Clinical Trials Group. Journal of Clinical Oncology, 21, 3025-3034. https://doi.org/10.1200/jco.2003.06.099

[48] Kosmidis, P., Mylonakis, N., Nicolaides, C., Kalophonos, C., Samantas, E., Boukovinas, J., Fountzilas, G., Skarlos, D., Economopoulos, T., Tsavdaridis, D., Papakostas, P., Bacoyiannis, C. and Dimopoulos, M. (2002) Paclitaxel plus Carboplatin Versus Gemcitabine plus Paclitaxel in Advanced Non-Small-Cell Lung Cancer: A Phase III Randomized Trial. Journal of Clinical Oncology, 20, 3578-3585. https://doi.org/10.1200/jco.2002.12.112

[49] Smit, E.F., van Meerbeeck, J.P., Lianes, P., Debruyne, C., Legrand, C., Schramel, F., Smit, H., Gaafar, R., Biesma, B., Manegold, C., Neymark, N. and Giaccone, G. (2003) Three-Arm Randomized Study of Two Cisplatin-Based Regimens and Paclitaxel plus Gemcitabine in Advanced Non-Small-Cell Lung Cancer: A Phase III Trial of the European Organization for Research and Treatment of Cancer Lung Cancer Group_EORTC 08975. Journal of Clinical Oncology, 21, 3909-3917. https://doi.org/10.1200/JCO.2003.03.195

[50] Buccheri, G.F., Ferrigno, D., Curcio, A., Vola, F. and Rosso, A. (1989) Continuation of Chemotherapy versus Supportive Care Alone in Patients with Inoperable NonSmall Cell Lung Cancer and Stable Disease after Two or Three Cycles of MACC. Results of a Randomized Prospective Study. Cancer, 63, 428-432.

https://doi.org/10.1002/1097-0142(19890201)63:3<428::AID-CNCR2820630305>3.0 .CO;2-V

[51] Smith, I.E., O’Brien, M.E., Talbot, D.C., Nicolson, M.C., Mansi, J.L., Hickish, T.F., Norton, A. and Ashley, S. (2001) Duration of Chemotherapy in Advanced NonSmall-Cell Lung Cancer: A Randomized Trial of Three versus Six Courses of Mitomycin, Vinblastine, and Cisplatin. Journal of Clinical Oncology, 19, 1336-1343. https://doi.org/10.1200/jco.2001.19.5.1336

[52] Socinski, M.A., Schell, M.J., Peterman, A., Bakri, K., Yates, S., Gitten, R., Unger, P., Lee, J., Lee, J.H., Tynan, M., Moore, M. and Kies, M.S. (2002) Phase III Trial Comparing a Defined Duration of Therapy versus Continuous Therapy Followed by Second-Line Therapy in Advanced-Stage IIIB/IV Non-Small-Cell Lung Cancer. Journal of Clinical Oncology, 20, 1335-1343.

[53] Bezjak, A., Lee, C.W., Ding, K., Brundage, M., Winton, T., Graham, B., Whitehead, M., Johnson, D.H., Livingston, R.B., Seymour, L. and Shepherd, F.A. (2008) Quality-of-Life Outcomes for Adjuvant Chemotherapy in Early-Stage Non-Small-Cell Lung Cancer: Results from a Randomized Trial, JBR.10. Journal of Clinical Oncology, 26, 5052-5059. https://doi.org/10.1200/JCO.2007.12.6094

[54] NSCLC Meta-Analyses Collaborative Group, Arriagada, R., Auperin, A., Burdett, S., Higgins, J.P., Johnson, D.H., Le Chevalier, T., Le Pechoux, C., Parmar, M.K., Pignon, J.P., Souhami, R.L., et al. (2010) Adjuvant Chemotherapy, with or without Postoperative Radiotherapy, in Operable Non-Small-Cell Lung Cancer: Two Meta-Analyses of Individual Patient Data. The Lancet, 375, 1267-1277. https://doi.org/10.1016/S0140-6736(10)60059-1

[55] Winton, T., Livingston, R., Johnson, D., Rigas, J., Johnston, M., Butts, C., Cormier, Y., Goss, G., Inculet, R., Vallieres, E., Fry, W., Bethune, D., Ayoub, J., Ding, K., Seymour, L., Graham, B., Tsao, M.S., Gandara, D., Kesler, K., Demmy, T. and Shepherd, F., National Cancer Institute of Canada Clinical Trials Group; National Cancer Institute of the United States Intergroup JBR.10 Trial Investigators (2005) 
Vinorelbine plus Cisplatin vs. Observation in Resected Non-Small-Cell Lung Cancer. The New England Journal of Medicine, 352, 2589-2597. https://doi.org/10.1056/NEJMoa043623

[56] Douillard, J.Y., Rosell, R., De Lena, M., Carpagnano, F., Ramlau, R., Gonzáles- Larriba, J.L., Grodzki, T., Pereira, J.R., Le Groumellec, A., Lorusso, V., et al. (2006) Adjuvant Vinorelbine plus Cisplatin versus Observation in Patients with Completely Resected Stage IB-IIIA Non-Small-Cell Lung Cancer (Adjuvant Navelbine International Trialist Association [ANITA]): A Randomised Controlled Trial. The Lancet Oncology, 7, 719-727. https://doi.org/10.1016/S1470-2045(06)70804-X

[57] Zatloukal, P., Petruzelka, L., Zemanová, M., Kolek, V., Skricková, J., Pesek, M., Fojtů, H., Grygárková, I., Sixtová, D., Roubec, J., et al. (2003) Gemcitabine plus Cisplatin vs. Gemcitabine plus Carboplatin in Stage IIIb and IV Non-Small Cell Lung Cancer: A Phase III Randomized Trial. Lung Cancer, 41, 321-331. https://doi.org/10.1016/S0169-5002(03)00233-2

[58] Rocchi, P., Mattioli, C., Rocchi, M.B., Mattioli, R., Lippe, P., Trivisonne, R., Buzzi, F., De Signoribus, G., Tuveri, G., Rossi, G., et al., (2003) Randomized, Multicenter, Phase II Study of Gemcitabine plus Cisplatin versus Gemcitabine plus Carboplatin in Patients with Advanced Non-Small Cell Lung Cancer. Lung Cancer, 41, 81-89. https://doi.org/10.1016/S0169-5002(03)00140-5

[59] Hirabayashi, M., Endoh, K., Teramachi, M., Okuda, M., Yamaguchi, K., Fukuda, K., Tokuhisa, H., Kagioka, H., Nakai, N. and Nakade, M. (2004) Phase II Study of Carboplatin and Weekly Paclitaxel Combination Chemotherapy in Advanced NonSmall Cell Lung Cancer: A Kansai Clinical Oncology Group Study. Lung Cancer, 44, 355-362. https://doi.org/10.1016/j.lungcan.2003.12.001

[60] Ayabe, T., Tomita, M., Chosa, E., Ikenoue, M., Shirasaki, Y. and Nakamura, K. (2014) Chemotherapy (Gemcitabine plus Carboplatin versus Paclitaxel plus Carboplatin) in Elderly Patients with Non-Small Cell Lung Cancer. Journal of Cancer Therapy, 5, 281-296. https://doi.org/10.4236/jct.2014.53035

[61] Ayabe, T., Tomita, M. and Nakamura, K. (2013) Adjuvant Chemotherapy of Gemcitabine plus Carboplatin versus Paclitaxel plus Carboplatin in Patients with Resected Non-Small Cell Lung Cancer. Journal of Cancer Therapy, 4, 15-23.

https://doi.org/10.4236/jct.2013.48A003

[62] United Kingdom Department of Health (2007) Guidance on the Routine Collection of Patient Reported Outcome Measures (PROMs).

[63] Rogers, S.N. (2010) Quality of Life Perspectives in Patients with Oral Cancer. Oral Oncology, 46, 445-447. https://doi.org/10.1016/j.oraloncology.2010.02.021

[64] Efficace, F., Bottomley, A., Coens, C., Van Steen, K., Conroy, T., Schöffski, P., Schmoll, H., Van Cutsem, E. and Köhne, C.H. (2006) Does a Patient's Self-Reported Health-Related Quality of Life Predict Survival beyond Key Biomedical Data in Advanced Colorectal Cancer? European Journal of Cancer, 42, 42-49.

[65] Deshpande, P.R., Rajan, S., Sudeepthi, B.L. and Abdul Nazir, C.P. (2011) PatientReported Outcomes: A New Era in Clinical Research. Perspectives in Clinical Research, 2, 137-144. https://doi.org/10.4103/2229-3485.86879

[66] Kozma, C.M., Reeder, C.E. and Schulz, R.M. (1993) Economic, Clinical, and Humanistic Outcomes: A Planning Model for Pharmacoeconomic Research. Clinical Therapeutics, 15, 1121-1132; Discussion 1120. 


\section{Abbreviation}

GEM: Gemcitabine, CBDCA: Carboplatin, PTX: Paclitaxel, CDDP: Cisplatin, DOC: Docetaxel, QOL-ACD: the quality of life questionnaire for cancer patients treated with anticancer drugs, Anti-aging quality of life assessment: AA-QOL.

Submit or recommend next manuscript to SCIRP and we will provide best service for you:

Accepting pre-submission inquiries through Email, Facebook, LinkedIn, Twitter, etc. A wide selection of journals (inclusive of 9 subjects, more than 200 journals)

Providing 24-hour high-quality service

User-friendly online submission system

Fair and swift peer-review system

Efficient typesetting and proofreading procedure

Display of the result of downloads and visits, as well as the number of cited articles

Maximum dissemination of your research work

Submit your manuscript at: http://papersubmission.scirp.org/

Or contact alc@scirp.org 